日本水処理生物学会誌

Jap. J. Water Treat. Biol.,

Vol.28. No.2, 1992

\title{
1991年秋の琵琶湖のアオコ
}

\section{The Aoko (water-bloom of blue-green algae)of Lake Biwa in autumn of 1991}

\author{
根来 健一郎 \\ Ken-ichiro Negoro
}

\begin{abstract}
The so-called Aoko in Japanese, namely the water-bloom of blue-green algae, occurred in late September of 1991 in the narrow and shallow canal of Seta, the southernmost part of Lake

The Aoko was composed of the following blue-green algae : Oscillatoria tenuis (57 77\%), Microystis wesenbergii (16 $\sim 34 \%$ ), Microcystis aeruginosa (4\%), Anabaena spiroides var. crassa ( $1 \sim 3 \%)$, Anabaena affinis ( $0 \sim 1 \%)$, and Oscillatoria kawamurae (1\%).
\end{abstract}

琵琶湖の最南端、唯一の排水河川である瀬田川が始 まる附近に、矢橋人工島が湖南中部流域下水道浄化セ ンターの建設のために造られたのは、今から17前のこと である。この人工島は幅約 $0.8 \mathrm{~km}$ 、長さ約 $1.0 \mathrm{~km}$ で、面 積は $0.73 \mathrm{~km}^{2}$ であるが、近年は矢橋帰帆島の名で呼ばれ ているようである。そしてこの人工島は草津市の矢橋湖 岸との間に、細長い水帯(著者はこれを矢橋狭水路と呼 んでいる)を隔てて、湖岸との間を矢橋大橋で連結され ている。この矢橋狭水路は、全体として弧形をしていて (人工島を弧の内側に抱く)、長さ約 $2.7 \mathrm{~km}$ 、幅約 $400 \mathrm{~m}$ 、 深さ $1 \sim 2 \mathrm{~m}$ 、水は常時殆んど停滞していて、浮遊性の 微生物に富み、琵琶湖中で毎年最も早期にアオコを生ず る水域として知られている。
矢橋狭水路のアオコは、年によると、すでに7月中旬 に発生するが、昨1991年には夏季には全く発生せず、や っと9月下旬になって発生を見た。著者が調査を行った のは9月29日であったが、当日は晴天で、アオコ標本の 採集時の午前 10 時 15 分における気温は $21.7^{\circ} \mathrm{C}$ 、水温は $23^{\circ} \mathrm{C}$ あっった。アオコの最もよく発達していた矢橋大橋 附近(橋の南側東湖岸の舟だまり)で探集したアオコの種 類構成を、藍藻個体あるいは群体の数の比率で、3回 $(A, B, C)$ にたって調べたところ、次のような結果を得た。

\section{アオコの藍類種類構成}

\begin{tabular}{|c|c|c|c|}
\hline & {$[\mathrm{A}]$} & [B] & [C] \\
\hline Microcystis aeruginosa Kutzing & $4 \%$ & $4 \%$ & $4 \%$ \\
\hline Microcystis wesenbergii Komarek & 16 & 34 & 31 \\
\hline Oscillatoria tenuis Agardh & 77 & 57 & 60 \\
\hline Oscillatoria kawamurae Negoro & 1 & 1 & 1 \\
\hline Anabaena affinis Lemmermann & 0 & 1 & 1 \\
\hline \multicolumn{4}{|l|}{ Anabaena spiroides Klebahn } \\
\hline \multirow[t]{2}{*}{ var. crassa Lemmermann } & 1 & 3 & 3 \\
\hline & $99 \%$ & $\overline{100 \%}$ & $100 \%$ \\
\hline
\end{tabular}

Aでは他にMelosira granulataと Euglena spが少数、Bでは 他にMelosira granulate と Pediastrum biwaeが少数見られた。

要するに1991年秋の琵琶湖(矢橋狭水路)のアオコは、 Oseillatoria tenuis と Microcystis wesenbergiiを主体とする もので、特にOseillatoria tenuisが多いことに特徴があり、 しかもこの萿の系状体は通常琵琶湖に広く浮遊して出現 
するものより著しく長かった $(800 \sim 900 \mu \mathrm{m})$ 。

1987年9月15日を中心として、その前後䄪15日間にわ たって、琵琶湖南湖(副湖盆)の大津市の市街地に接する 湖岸(浜大津から膳所にかけて)に、大規模のアオコが発 生した。著者は9月15日に、浜大津、島の関、打出浜、 弓ヶ浜(由美浜)などて、アオコの採集を行ったが、この 折のアオコは殆どMierocystis wesenbergñのみによって構 成されていて、他には僅かにMicrocystis aeruginosaや Botryococcus brauniiを極めて少数混ずるに過ぎなかった。 1990 年 8 月下旬に打出浜に出現したアオコは、 Microcystis wesenbergii, Microcystis aenuginosa, Anabaena affinis, Anabaena spiroides var. crassa, Anabaena macrospora var. crassa, Oscillatoria tenuis, およびOscillatoria kawamurae の7種類の藍涤から構成されたもので、中でも Microcystis wesenbergii (63.5\%)、Anabaena spiroides var. crassa (14.4\%)、Oscillatoria tenuis $(12.0 \%)$ などが主体を成して いた。

1991年秋の矢橋狭水路のアオコは、1990年8月下旬の 打出浜のアオコにその組織がよく似ている。殊に Oscillatoria kawamuraeが加っている点で両者が一致して いて、これは従来の琵琶湖のアオコには全く見られなか ったことである。

Oscillatoria kawamurae Negoroは、川村多実二. 宮地 伝三郎両氏が、1938年7月30日に満州の興凱湖 $($ Chankasee $=$ Hsin-kai-hu $)$ 附近の 1 小池から収集して著者 に提供せられた資料中から、著者が発見して1940年に新 種として記載したもので、その後日本の近畿の2～3の小 池からも見出されたが、琵琶湖に扔ける出現は1990年夏 のアオコ中から初めて著者によって確認されたものであ る。本種はOscillatoria princepsに最も近縁のものである が、系状体の幅が遥かに大きいこと(系状体の幅は、Osc. princepsでは16〜16 $\mu \mathrm{m}$ であるのに対して、Osc. kawamuraeでは56〜 78 $\mu \mathrm{m}$ である)、系状体の末端部が決して 曲らないことによって、Osc. princepsとは明かに区別さ れる。系状体の幅の大きいことは、Oscillatoria属中随一 である。なおOsc. kawamuraeでは、各細胞中のガス胞が 甚だ大きくて、各細胞に定った数(3あるいは4個)だけ存 在し、しかもそれらが互いに規則正しく配列し、系状体 の縦軸の方向に、その数に相当するだけの本数の蜾旋を 形成していることは、注目に值する特異な事実である。

1991 年秋のアオコの候には、矢橋狭水路の全域に Oscillatoria kawamuraeは可成り多量に浮遊して生息して いた。アオコの構成種の個体あるいは群体の数から見た 組織では、僅かに $1 \%$ 前後を占めるに止っているが、こ の藻の系状体の1本が可成り大きい体積を占めることに よって、相観的には極めて顕著なものである。

\section{引用および参考文献(References)}

1) Geitler, L. (1925): Gyanophyceoe. A, Paseher's Suesswasserflora, 12, Jena.

2) Huber-Pestolozzi, G. (1938) : Blaualgen(Das Phytoplankton des Susswassers).

A. Thienemann's Binnengewasser, 16 (1). Stuttgart.

3) Komarek, g. (1985): Die taxonomische Revision der planktisehen Blaualgen der Tschechoslowakei. H. Ettl's Algologische Studien, 10-206.Praha.

4) 根来健一郎(1940)：満州産陸水藍莯類。関東州及び 満州国陸水生物調查書、523-538頁。関東州庁土木 部。

5) Negoro. K. (1943): Untersuchunger uber die Planktoncyanophyecen der Binnengewasser der Mandschurei. I. Sci Rep, Tokyo Bunrika Daigaku, Sec B, 6 (94)、69-89。

6) 根来健一郎(1968)：琵琶湖の植物性プランクトン。北 村四郎編、滋賀県植物誌、275-330。大阪。

7) 根来健一郎(1973)：藍桬植物(Cyanophyta)。上野益 三編、川村日本淡水生物学、10-27

8) 根来健一郎(1986)：琵琶湖の浮遊性藍藻Anabaena affinis Lemmermann. 日本水処理生物学会誌、22、(2), 1-5。

9) 根来健一郎(1991)：1990年夏の琵琶湖のアオコ(青 粉)。植物分類地理、42 (2)、159-164

10) Smith, G. M.(1920) : Phytoplankton of the Inland Lakes of Wisconsin, Part 1. Madison. 

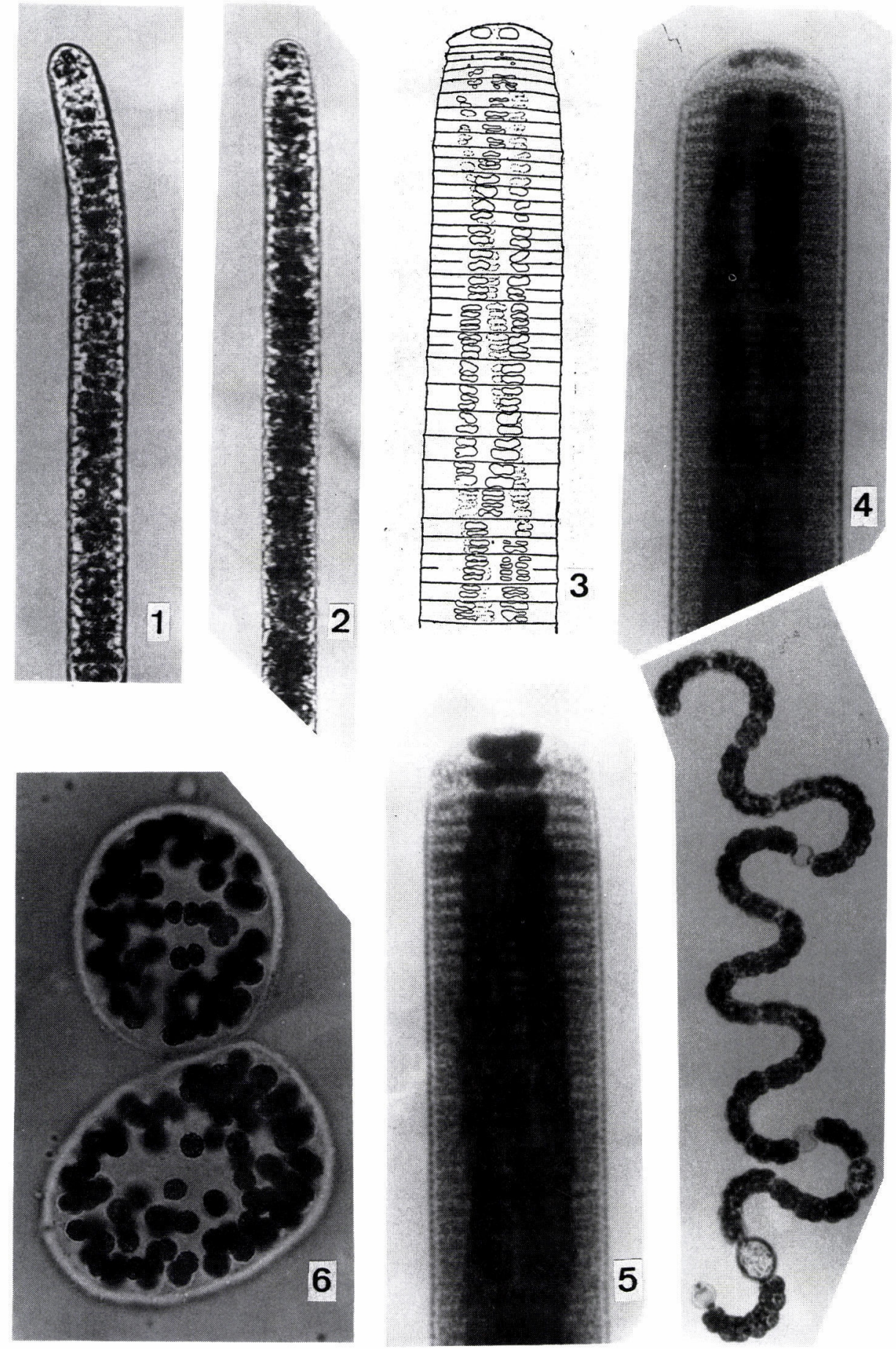

\section{$1,2 \stackrel{10 \mu \mathrm{m}}{\longrightarrow} \quad 3 \stackrel{10 \mu \mathrm{m}}{\sim} 4 \sim 7^{10 \mu \mathrm{m}}$}

1、2 Oscillatoria tenuis

$6 \quad$ Microcystis wesenhergii
3、4、5 Oscillatoria kawamurae(第3図は著者が新種記載に用いたもの) 7 Anabaena spiroides var. crassa 